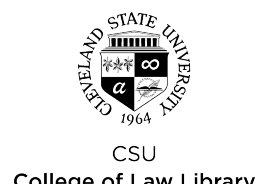

Cleveland State University

College of Law Library

\title{
EngagedScholarship@CSU
}

2011

\section{It's Good to be Autonomous: Prospective Consent, Retrospective Consent, and the Foundation of Consent in the Criminal Law}

Jonathan Witmer-Rich

Cleveland State University, j.witmerrich@csuohio.edu

Follow this and additional works at: https://engagedscholarship.csuohio.edu/fac_articles

Part of the Criminal Law Commons

How does access to this work benefit you? Let us know!

\section{Original Citation}

Jonathan Witmer-Rich, It's Good to be Autonomous: Prospective Consent, Retrospective Consent, and the Foundation of Consent in the Criminal Law, 5 Criminal Law and Philosophy 377 (2011)

This Article is brought to you for free and open access by the Faculty Scholarship at EngagedScholarship@CSU. It has been accepted for inclusion in Law Faculty Articles and Essays by an authorized administrator of EngagedScholarship@CSU. For more information, please contact research.services@law.csuohio.edu. 


\title{
It's Good to be Autonomous: Prospective Consent, Retrospective Consent, and the Foundation of Consent in the Criminal Law
}

\author{
Jonathan Witmer-Rich
}

Published online: 4 June 2011

(C) Springer Science+Business Media B.V. 2011

\begin{abstract}
What is the foundation of consent in the criminal law? Classically liberal commentators have offered at least three distinct theories. J.S. Mill contends we value consent because individuals are the best judges of their own interests. Joel Feinberg argues an individual's consent matters because she has a right to autonomy based on her intrinsic sovereignty over her own life. Joseph Raz also focuses on autonomy, but argues that society values autonomy as a constituent element of individual well-being, which it is the state's duty to promote.

The criminal law's approach to the problem of non-contemporaneous consent-prospective consent and retrospective consent-casts a unique light on the differences among these three justifications. Peter Westen claims neither Mill's nor Feinberg's justifications for consent fully explains how non-contemporaneous consent is treated in the criminal law. Specifically, Mill's "self-interest" conception explains the criminal law's limited recognition of prospective consent, but cannot explain its total rejection of retrospective consent. Conversely, Feinberg's "sovereign autonomy" conception explains why the criminal law rejects retrospective consent, but cannot explain why the law recognizes irrevocable prospective consent only in limited circumstances.

I resolve this dilemma by explaining that Raz's "autonomy is good" conception is consistent with both the criminal law's limited recognition of irrevocable prospective consent and its total rejection of retrospective consent. This suggests the existing criminal law embodies Raz's theory that it is the duty of the state to promote morality, in particular the moral good of individual well-being through living autonomously. In contrast, the criminal law's treatment of consent would have to be modified if it were to reflect Mill's "self-interest" conception, or Feinberg's "sovereign autonomy" conception.
\end{abstract}

Keywords Consent $\cdot$ Autonomy $\cdot$ Criminal law $\cdot$ Harm $\cdot$ Prospective consent . Retrospective consent

J. Witmer-Rich $(\bowtie)$

Cleveland-Marshall College of Law, Cleveland State University,

2121 Euclid Ave., LB 138, Cleveland, OH 44115, USA

e-mail: jwitmerrich@law.csuohio.edu 


\section{Introduction}

Consent is a defense to many crimes: "it can transform the most horrific crimes into noncrimes, turning 'rape' into sexual intercourse, 'maiming' into therapeutic surgery, 'kidnapping' into vacation, 'trespass' into hospitality, and 'theft' into gift-giving." ${ }^{1}$ Why does consent transform some horrific crimes into non-crimes? What is the "moral magic" 2 consent possesses in the criminal law?

I argue that consent in the criminal law is grounded on the view that being autonomous is a constituent element of the good life-a conception of autonomy articulated by Joseph Raz. ${ }^{3}$ In contrast, the criminal law's approach to consent is inconsistent with-cannot be explained by-two other classic conceptions of consent. Specifically, it cannot be fully explained by J.S. Mill's argument that we value consent because the individual is the best judge of her own interests. ${ }^{4}$ Nor can it be fully explained by Joel Feinberg's theory that we value consent because the individual has an intrinsic right to autonomy based on her sovereignty over her self. ${ }^{5}$

Each of these three theories of consent is classically liberal, as each gives primacy to the values of liberty and autonomy. With respect to consent, all three theories point in the same direction much of the time. For example, as explained in Part II, any of these theories is sufficient to explain why coerced consent, or consent given by an incompetent person, is legally invalid.

In certain contexts, however, these theories point in different directions. In particular, as Peter Westen has noted, the criminal law's approach to the problem of non-contemporaneous consent—prospective and retrospective consent— c cast[s] light on the debate among commentators as to the justification for" consent as a defense to a criminal charge, i.e. "allowing a subject $S$ to authorize $A$ to subject her to conduct $x$ that would otherwise be an offense against her." ${ }^{6}$ As explained below, the issue of non-contemporaneous consent exposes rifts among these three theories of consent in a way that more common issues of consent do not. Stated differently, Mill's, Feinberg's, and Raz's respective theories of consent each have different implications for how the criminal law should value (or refuse to value) certain cases of prospective consent and retrospective consent. Thus a careful examination of how the criminal law currently approaches these unusual cases of noncontemporaneous consent helps illuminate which theory of consent is really at work in the criminal law. ${ }^{7}$

\footnotetext{
1 Westen (2004, p. 15).

2 Hurd (1996).

${ }^{3}$ Raz (1988, p. 408). I refer to Raz's conception of autonomy as the "autonomy is good" theory. Raz's conception is set forth more fully in Part I.

4 Westen [2004, pp. 127-28 and nn. 56-59 (quoting Mill 1859)]. I refer to this as the "self-interest" theory, as it depends crucially on vindicating the individual's evaluation of her own interests.

5 Westen [2004, pp. 127-28 (quoting Feinberg 1989)]. I refer to this as the "sovereign autonomy" theory, as it is based on the individual's inherent self-sovereignty.

6 Westen (2004, p. 263). I follow Westen's convention of using $S$ to represent the subject of whom consent is sought, $x$ to represent the conduct or transaction for which consent is sought, and $A$ to represent the actor seeking $S$ 's consent to $x$.

7 In speaking of "the criminal law," I refer to actual criminal law doctrine as it exists (focusing on American and British law), not some ideal conception of the criminal law. I focus on consent as it operates in the criminal law, as opposed to the distinct debate over consent as a justification for the state's political authority. See, e.g., Simmons (2010).
} 
Westen argues that neither Mill's "self-interest" theory nor Feinberg's "sovereign autonomy" theory can adequately explain how current criminal law doctrine treats the issues of prospective consent and retrospective consent. More specifically, Westen identifies the following puzzle. Mill's "self-interest" theory can explain the criminal law's approach to prospective consent, but cannot explain the criminal law's total rejection of retrospective consent: "if $S$ 's self-interest were the goal that jurisdictions invoked retrospective consent to serve, jurisdictions would recognize the legitimacy of retrospective consent far more often than they presently do, for $S$ knows the most about herself after $x$ occurs when she is able to place it in the context of her life as a whole." ${ }^{8}$ In contrast, Feinberg's "sovereign autonomy" theory is sufficient to explain the criminal law's total rejection of retrospective consent, but cannot explain the criminal law's restrictive approach to prospective consent: "if doctrines of prospective prescriptive consent were based on notions of $S$ 's autonomy (as opposed to $S$ 's interests), jurisdictions would recognize prospective ... consent far more widely than they presently do, rather than treating it as an exception to a normative presumption in favor of contemporaneous consent." 9

I resolve this puzzle by considering Raz's "autonomy is good" conception of consent, introduced in Part II. Parts III and IV explain that Raz's "autonomy is good" theory, unlike the two considered by Westen, is sufficient to explain how the criminal law treats both prospective consent (Part III) and retrospective consent (Part IV). Thus the criminal law's current approach to instances of non-contemporaneous consent suggests that consent in the criminal law is based on Raz's conception that "autonomy is good," and not on Mill's "self-interest" theory or Feinberg's "sovereign autonomy" theory.

\section{Conceptions of Consent: Mill, Feinberg, Raz}

Before examining how the three conceptions of consent interact with the criminal law, two preliminary matters must be addressed: first, providing a definition of "consent," and second, more fully articulating the three competing conceptions.

First, the definition: consent is a communicative act by $S$ to conduct $x$ by $A$ which alters the moral rights and duties of $S$ and $A$ relative to each other. ${ }^{10}$ Thus consent operates against a background of $S$ 's and $A$ 's legal rights and duties, such as each party's right to bodily integrity and sexual autonomy, and each party's concomitant duty not to interfere with another's bodily integrity or sexual autonomy. In that context, $S$ 's authority to give or withhold consent enables her to alter those rights and duties.

Legally valid consent consists of two components. It first requires the presence of "factual consent," which is simply $S$ 's communication to $A$ of $S$ 's acquiescence in $x$. ${ }^{11}$ Factual consent is a necessary component of legally valid consent, but is not sufficient. $S$ 's factual consent must also constitute "normative consent" or "legally valid consent." $S$ 's factual consent is legally valid when it is given under sufficient conditions of freedom,

\footnotetext{
${ }^{8}$ Westen (2004, p. 263).

9 Westen (2004, p. 263).

${ }^{10}$ Hyams (2011, p. 111) ("Consent is an act, an intentionally performed behaviour that may take the form of either an action or an omission," which "allows agents to change their rights, and the duties and correlate with them. Consent legitimizes by changing rights: when an agent consents, she either waves her rights and grants liberties to another agent, or she waives her liberties and grants rights to another agent, or she does both of these things.”); Kleinig (2010, p. 5).

11 Westen (2004, pp. 4-5).
} 
knowledge, and competence. ${ }^{12}$ Determining specifically how much freedom, knowledge, and competence is required for consent to be legally valid is a difficult normative question over which there is significant disagreement. ${ }^{13}$

With that general definition of consent in mind, I now turn to providing a fuller explanation of Mill's "self-interest" theory, Feinberg's "sovereign autonomy" theory, and Raz's "autonomy is good" theory.

\section{Mill: Individuals are the Best Judges of Their Interests}

Mill argues that society should value $S$ 's consent because $S$ is the best judge of what serves her own interests. Society's interest in any individual "is fractional, and altogether indirect: while, with respect to his own feelings and circumstances, the most ordinary man or woman has means of knowledge immeasurably surpassing those that can be possessed by any one else." ${ }^{14}$ Accordingly, when society attempts to judge for $S$ what is in her best interest, that judgment "must be grounded on general presumptions; which may be altogether wrong, and even if right, are as likely as not to be misapplied to individual cases, by persons no better acquainted with the circumstances of such cases than those are who look at them merely from without." ${ }^{15}$ Accordingly, "in each person's own concerns, his individual spontaneity is entitled to free exercise.... All errors which he is likely to commit against advice and warning, are far outweighed by the evil of allowing others to constrain him to what they deem his good." 16

Thus, Mill's account is instrumental-we value $S$ 's consent because of the resulting good, namely the advancement of $S$ 's interests. And the specific mechanism by which society achieves this good result is by permitting $S$ to choose for herself-as she is the best judge of what serves her interests. Under Mill's "self-interest theory," $S$ 's consent to $x$ with $A$ is a defense to a criminal charge because $S$ is the best judge (perhaps not a perfect judge, but on balance a better judge than society) of whether $x$ furthers her interests.

\section{Feinberg: The Sovereign Right of Autonomy}

Joel Feinberg argues that individual consent matters, not because persons are better judges of their own interests, but because persons have a right to autonomy based on their selfsovereignty. This right of autonomy is not instrumental-it does not depend on the judgment that the individual will make good choices.

The idea of self-sovereignty is the core of Feinberg's conception of autonomy. Speaking first of state sovereignty, Feinberg notes that "sovereignty is basic and underivative. Sovereignty is, in a sense, an ultimate source of authority." ${ }^{17}$ Feinberg proceeds to make the case for understanding personal autonomy as analogous to state sovereignty. ${ }^{18}$

\footnotetext{
12 Westen (2004, p. 7) (factual consent has normative force when it is given "under conditions of a certain kind-namely, such conditions of knowledge, competence, freedom, and motivation to acquiesce as are deemed necessary to give the expression legal effect"); Hyams (2011, pp. 112-115); Kleinig (2010, p. 13).

13 Feinberg (1989, pp. 189-343) (discussing failures of consent due to "coercive force," "coercive offers," "defective belief," and "incapacity"); Westen (2004, pp. 119-124).

14 Mill (1859, Ch. IV p. 4).

15 Mill (1859, Ch. IV p. 4).

16 Mill (1859, Ch. IV p. 4).

${ }^{17}$ Feinberg (1989, p. 48).

18 Feinberg (1989, pp. 51-52).
} 
Feinberg explains that "to say that I am sovereign over my bodily territory is to say that I, and I alone, decide (so long as I am capable of deciding) what goes on there." ${ }^{19}$ In the same way that state sovereignty is "basic and underivative," the individual's right to autonomy is a "right of self-determination" that is "entirely underivative, as morally basic as the good of self-fulfillment itself." 20 "The life that a person threatens by his own rashness is after all his life; it belongs to him and to no one else. For that reason alone, he must be the one to decide-for better or worse-what is to be done with it in that private realm where the interests of others are not involved." 21

Feinberg recognizes that this conception of "sovereign autonomy" has significant implications for the relationship between the values of autonomy and liberty. Because Feinberg understands autonomy as akin to self-sovereignty - an underivative birthrighthe recognizes that a sovereign person may choose to alienate or trade off parts of her liberty. While "freedom is an important good in human life,... [i]t is very important to recognize that freedom is one kind of good among many, that persons have been known to get along well with very little of it, and that rational persons are often willing to 'trade' large amounts of it for goods of other kinds, including simple contentment." 22 Accordingly, "[t]he de jure autonomous person will surely reserve the right to 'trade off' his de facto freedoms for goods of other kinds, as measured on his own scale of values and determined by his own judgments." 23

Thus, "[t]here is no paradox... when a morally autonomous person exercises his sovereign right of self-government to diminish his own de facto freedom of action." 24 Looking back to the analogy to state sovereignty, Feinberg notes that "there is neither conceptual nor (necessarily) moral difficulty when a political state renounces some part of its sovereignty." 25 Accordingly, "[i]f we transfer the whole concept of sovereignty from the nation to the person, then we should expect the same implications for the personal forfeiture of autonomy." 26 The bottom line is that "[a] perfectly autonomous person would have in Mill's words the 'power of voluntarily disposing of his own lot in life,' even if that involved forfeiture of his de facto freedom in the future."27

\section{Raz: Autonomy is an Element of the Good Life}

Joseph Raz articulates a theory of autonomy that differs from both Mill and Feinberg. Raz argues that we value $S$ 's choices because "[a]utonomy is a constituent element of the good life." 28

Raz's conception of autonomy relates fundamentally to his view that "it is the function of governments to promote morality," and that "[m]orality is thought to be concerned with

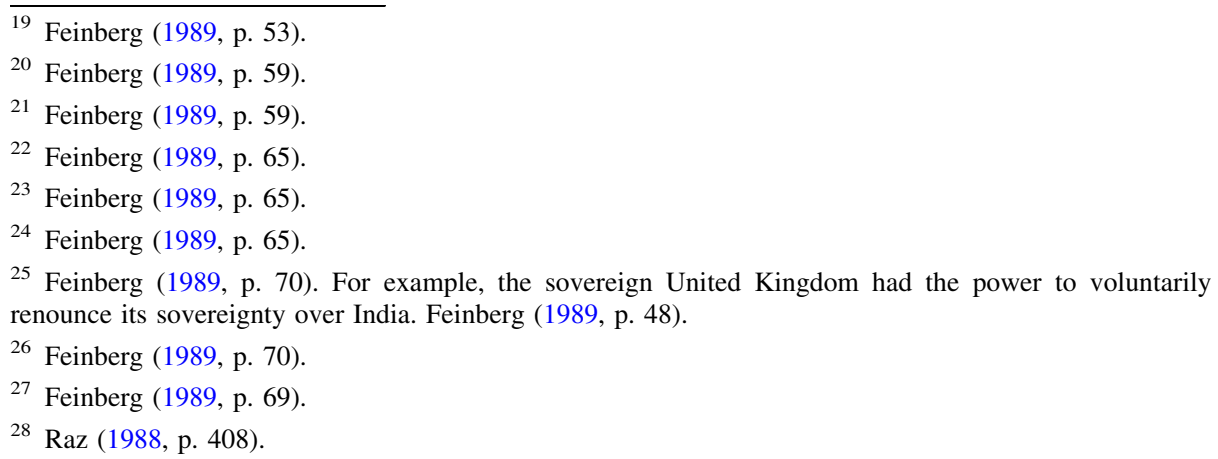


the advancement of the well-being of individuals." ${ }^{29}$ Raz claims that "[a] person's wellbeing consists in his successful pursuit of valuable, willingly embraced goals." ${ }^{30}$ Individual well-being requires that the individual "adopt and pursue goals because [she] believes in their independent value." 31 "Autonomy means that a good life is a life which is a free creation." 32 Autonomy is valuable, then, because it is an essential component of individual well-being: Raz's "concern for autonomy is a concern to enable people to have a good life." 33 On this view, the government should promote individual autonomy because it facilitates and is a constituent component of individual well-being.

Turning to the issue of consent, Raz notes that one "common instrumental justification of consent turns not on the benefits of consenting but on the benefit of being able to consent. It is sometimes a way of endowing a person with a responsibility that trains him to fulfill various roles in the future, or that it is hoped will change his character for the better, or that endows its holder with prestige, or that gives him a certain hold on other people and makes them more likely to act in his interests." ${ }^{44}$ That is to say, $S$ 's consent to $x$ is honored because the state of being able to choose-being autonomous-is itself good.

The salient feature of Raz's conception of autonomy is his understanding of autonomy not as a natural birthright (as posited by Feinberg), but as a constituent element of individual well-being, which the state has a duty to promote.

\section{Consent in the Criminal Law: Freedom, Knowledge, and Competence}

Non-contemporaneous consent in the criminal law is a somewhat rare beast: defendants do not regularly claim that their otherwise criminal conduct is legal because of the victim's irrevocable prospective consent or her retrospective consent. In contrast, courts and commentators routinely grapple with the difficult questions of what conditions turn $S$ 's (contemporaneous) factual choice into legally valid consent. The debates often relate to which specific conditions of freedom, knowledge, and competence are required to make $S$ 's factual consent also constitute legally valid consent. ${ }^{35}$

Why, then, interrogate the underlying justification for consent by focusing on the relatively unusual issue of non-contemporaneous consent, rather than the sorts of knowledge,

\footnotetext{
${ }^{29} \operatorname{Raz}(1988$, pp. 415, 267).

$30 \operatorname{Raz}$ (1988, p. 288).

31 Raz identifies four conditions of personal well-being. First, well-being "consist[s] of the successful pursuit of goals which [the individual] has or should have." Second, the individual "adopt[s] and pursue[s] goals because [she] believes in their independent value." Third, an individual's "well-being depends, at the deepest level, on his action reasons and his success in following them." Fourth, "a person's well-being depends to a large extent on success in socially defined and determined pursuits and activities." Raz (1988, pp. 308-309).

$32 \operatorname{Raz}(1988$, p. 412).

$33 \operatorname{Raz}(1988$, p. 412).

34 Raz (1988, p. 86). See also Miller \& Wertheimer (2010, p. 79) ("people typically want to make decisions for themselves and the satisfaction of this desire is also a component of their well-being apart from the intrinsic value of making decisions for oneself"); Regan (1983, p. 129) ("we might sometimes want to let an individual do something foolish, which would harm her in the future, in order to encourage her to develop the ability to make good choices").

35 See, e.g., Feinberg (1989, pp. 189-343) (discussing failures of consent due to "coercive force," "coercive offers," "defective belief," and "incapacity"); Westen (2004, pp. 119-124) (explaining that legally valid consent depends on contested moral judgments, and providing examples of jurisdictions resolving those normative judgments in different ways).
} 
competence, and freedom that are required for legally valid consent? It is because that latter debate does not seem to shed light on the differences between Mill's, Feinberg's, and Raz's theories. That is to say, any of these three justifications broadly suffices to explain why factual consent must be given under sufficient conditions of knowledge, freedom, and competence. This is because all three theories, while distinct, are close cousins: they are all classically liberal justifications, sharing a core commitment to at least some version of liberty and individual autonomy.

In contrast, the issue of non-contemporaneous consent illuminates the very real differences among the three justifications. As Westen observes, the criminal law's approach to the problem of non-contemporaneous consent "cast[s] light on the debate among commentators as to the justification for allowing a subject $S$ to authorize $A$ to subject her to conduct $x$ that would otherwise be an offense against her." ${ }^{36}$ The explanation of this point is the central subject of this article. First, I offer a brief explanation of the prior claim-that debates about knowledge, competence, and freedom do not necessarily expose the differences among these three theories.

Mill justifies our deference to $S$ 's consent because of the signal her consent sends us about the advancement of her interests: when $S$ validly consents to $x$ with $A$, that signal is our best indication that $x$ advances $S$ 's self-interest. For this signaling function to operate reliably, $S$ 's factual choice must be made under sufficient conditions of freedom, knowledge, and competence. When $S$ 's factual choice is unduly coerced, or lacking necessary knowledge of the relevant facts, or when $S$ is incompetent to assess her interests, then the law is unable to rely on $S$ 's (coerced, or ignorant, or incompetent) choice as a reliable signal of whether $x$ is in $S$ 's best interests. While Mill's theory does not resolve precisely how much freedom, knowledge, and competence $S$ must possess for her "consent" signal to be reliable, the theory does explain why those conditions are essential for $S$ 's consent to be legally valid.

Feinberg, unlike Mill, does not rely on $S$ 's consent as a signal about what is in her selfinterest. Instead, Feinberg argues $S$ 's consent should be valued because $S$ has a sovereign right of self-determination, or autonomy. On this theory, when $S$ 's choices are improperly constrained by excessive coercion from $A, S$ no longer has the ability to shape her own life as she sees fit. A's coercion lessens or eliminates $S$ 's autonomy. The same is true if $S$ is deprived of sufficient knowledge about the choice she is making: if $S$ chooses $x$ because $A$ has materially deceived her about $x, S$ 's ability to direct her life is compromised. As for competence, if $S$ lacks the mental capacity necessary for self-governance, she cannot meaningfully operate as a self-sovereign. ${ }^{37}$

Raz's conception of autonomy is also able to explain these knowledge, competence, and freedom components of legal consent. Raz is not focused on $S$ 's inherent self-sovereignty, but rather on the fact that being autonomous enables $S$ to have-and is a constituent element of-a worthy life. For Raz, $S$ 's well-being consists of her "successful pursuit of valuable, willingly embraced goals." ${ }^{38}$ On this view, $S$ cannot achieve well-being if her choices are coerced, or if they result from deception, or if she is incompetent. Thus Raz explains that " $\mathrm{t}] \mathrm{o}$ be autonomous" in his sense, "agents have to meet three conditions: they must possess certain mental capacities, they must have an adequate range of valuable options, and they must enjoy independence from coercion and manipulation." 39

\footnotetext{
36 Westen (2004, p. 263).

37 See Feinberg (1989, pp. 189-343) (explaining why consent is invalid when given under conditions of

"coercive force," "coercive offers," "defective belief," or "incapacity").

38 Raz (1988, p. 288).

$39 \operatorname{Raz}(1988$, p. 369).
} 
I do not claim here that these different justifications of consent have no implications for what conditions of knowledge, competence, and freedom are necessary for legally valid consent. In the main, however, all three theories are consistent with the criminal law's approach to this question. Thus it is particularly fruitful to examine other aspects of consent that more crisply and definitively highlight the rifts among these conceptions. The issue of non-contemporaneous consent is particularly illuminating, as explained below.

\section{Prospective Consent and the Criminal Law}

In this section, I first describe the doctrine of prospective consent-when American and British jurisdictions recognize or refuse to recognize $S$ 's prospective consent-and then turn to what light that sheds on the underlying justification for consent.

\section{The Doctrine of Irrevocable Prospective Consent}

Generally speaking, as Douglas Husak explains, "[b]oth morality and law tend to privilege contemporaneous expressions of consent or nonconsent over prior conflicting preferences." 40 The criminal law does sometimes recognize irrevocable prospective consent, in two distinct types of cases: first, when $S$ later suffers under significantly diminished capacity, and second, when $S$ gives irrevocable prospective consent to the seizure of her property in a security agreement.

It is important to distinguish between "ordinary" prospective consent and expressly irrevocable prospective consent. When $S$ consents to $x$ in the future but makes no commitment that her consent cannot later be revoked, it is easy to conclude that $S$ 's prospective consent is neither intended nor understood to be irrevocable. In the criminal law, "persons are generally free to change their minds." ${ }^{41}$ The more difficult case is when $S$ gives prospective consent and, at the same time, expressly designates it as irrevocable.

\section{Diminished Capacity}

The classical example of irrevocable prospective consent is Homer's Odysseus, who receives the following counsel from Circe:

If any one unwarily draws in too close and hears the singing of the Sirens, his wife and children will never welcome him home again, for they sit in a green field and warble him to death with the sweetness of their song. ... Therefore pass these Sirens by, and stop your men's ears with wax that none of them may hear; but if you like you can listen yourself, for you may get the men to bind you as you stand upright on a cross-piece half way up the mast, and they must lash the rope's ends to the mast itself, that you may have the pleasure of listening. If you beg and pray the men to unloose you, then they must bind you faster. ${ }^{42}$

\footnotetext{
${ }^{40}$ Husak (2010, p. 116). See also Westen (2004, p. 248) ("as a legal matter, Anglo-American criminal law tends strongly to privilege a subject's contemporaneous assessments of her interests over her non-contemporaneous assessments").

41 Husak (2010, p. 121). See Tyson v. Trigg, 50 F.3d 436, 448 (7th Cir. 1995) (Posner, J.) ("If on Friday you manifest consent to have sex on Saturday, and on Saturday you change your mind but the man forces you to have sex with him anyway, he cannot use your Friday expression to interpose, to a charge of rape, a defense of consent or of reasonable mistake as to consent. You are privileged to change your mind at the last moment.").

42 Homer (Book XII).
} 
Homer follows Circe's advice, and his men refuse Homer's requests to unbind him as he hears the seductive Siren song.

As Westen observes, Odysseus's mast-tying experience is a case of diminished capacity: Odysseus gives consent to be constrained at a time he is in full possession of his faculties, and his men rely on that irrevocable consent to override his non-consent at a time his competence is severely compromised by the Sirens' song. ${ }^{43}$

The simplest cases of diminished capacity involve circumstances where the future conduct will occur at a time when $S$ is unconscious. Common medical examples include a living will, where $S$ prospectively consents to the termination of life-sustaining intervention, and prospective consent to surgical procedures. ${ }^{44}$ In the context of sex, Westen posits a hypothetical case where $S$ "seeks novel forms of intimacy with her husband" $A$ and challenges $A$ to see if he can have intercourse with her while she is sleeping. In this scenario, $A$ would have a defense to charges of sexual assault based on $S$ 's prospective consent, even though $A$ 's conduct occurred at a time when $S$ was incapable of contemporaneous consent. ${ }^{45}$

More difficult are cases when $S$ is not fully unconscious, but only less competent than she was earlier. Westen states that jurisdictions tend to privilege $S$ 's prospective consent over her contemporaneous non-consent "with respect to subjects who reasonably believe beforehand that, thought they may retain some competence to assess their own interests by the time of the event, their competence at that time will be substantially diminished...."46 Examples include an alcoholic who prospectively consents to $A$ forcibly seizing her car keys in the event she has more than a few drinks, or a person suffering from a mental disorder who prospectively consents to a 60-day period of institutionalization in the event that her psychiatrist deems it necessary. ${ }^{47}$

Thus the criminal law sometimes permits prospective consent to serve as a defense when $S$ is either incapable of contemporaneous consent or when she suffers some substantial diminished capacity contemporaneous with $x{ }^{48}$

Husak questions whether prospective consent is really doing the work in these cases. He argues that Odysseus's prospective consent was not what justified his sailors' refusal to untie him: "[i]f Odysseus had not issued his prior command to remain tied to the mast, his crew would have been equally justified in ignoring his subsequent pleas." ${ }^{49}$ More broadly, Husak argues that "the absence of consent is irrelevant to the justification of paternalism." ${ }^{50}$ It may be true that irrevocable consent is not an adequate justification for paternalism. But if the restraint in question is justified by the subject's irrevocable consent, then the restraint is not paternalistic - it is not justified by a concern to impose (unwanted) benefits on the individual. Instead, the restraint is justified by a desire to vindicate the individual's own prior decision. ${ }^{51}$

Husak focuses on whether paternalism is affected by irrevocable prospective consent, because he earlier concludes that an individual's irrevocable consent alone is insufficient to

\footnotetext{
43 Westen $(2004$, p. 253).

44 Westen (2004, pp. 248-249).

45 Westen (2004, p. 249).

46 Westen (2004, pp. 252-253).

47 Westen (2004, pp. 251-253).

48 Westen (2004, p. 254).

49 Husak (2010, p. 116).

50 Husak (2010, p. 123).

51 As Keith Hyams explains, arguments that appeal to "prescriptions that appropriately benefit agents" are not necessarily paternalistic: "paternalism requires, additionally, that the explanation claims that a moral prescription benefits agents by overruling their own decisions, for their own sakes." Hyams (2011, p. 117).
} 
justify our intervention. He argues that we should not recognize an individual's irrevocable prospective consent as against her contemporaneous non-consent, given that an "abundance of data confirms that persons are notoriously poor in predicting what they will want at a later time under different circumstances." ${ }^{52}$ Husak's argument has force if one accepts this premise - namely that the reason we honor $S$ 's consent is because $S$ is the best judge of her own interests. I return to this point in the next section.

The "hardest case," Joel Feinberg notes, "is that in which the conflicting decisions of earlier and later selves appear to be equally voluntary," i.e., made under similar conditions of freedom, knowledge, and competence. ${ }^{53}$ In that circumstance, the criminal law does not recognize irrevocable consent as a defense in the face of contemporaneous non-consent, ${ }^{54}$ save one exception: security agreements.

\section{Security Agreements}

Security agreements are a prominent feature of the private law of contracts, but do not typically figure in discussions of the criminal law. ${ }^{55}$ The basic concept is familiar: a security agreement gives a lender an interest in specific collateral (often property) owned by the borrower, and entitles the lender to repossess the collateral in the event of default by the borrower. ${ }^{56}$ It is easy to see how a security agreement is a form of irrevocable prospective consent: borrower $S$ 's voluntary consent when entering into the initial contract remains binding on her even if later, at the time of default, $S$ objects to the lender's repossession of her property.

Less commonly noted is the criminal law's role in facilitating security agreements. The lender's act of repossession meets the elements of criminal theft, except for the borrower's earlier irrevocable consent. When $S$ finances a car purchase from $A$ through a secured lending agreement, $S$ has granted her irrevocable consent for $A$ to physically take the car from her in the event of default, even if $S$ later wants to revoke her consent. If $A$ were prosecuted for theft of the car, $A$ would have a valid defense based on $S$ 's earlier irrevocable consent. ${ }^{57}$ Through a security agreement, a borrower gives "irrevocable consent [to the lender] to enter [the borrower's] premises to conduct a peaceful repossession in the case of default." 58

\footnotetext{
52 Husak (2010, p. 120).

53 Feinberg (1989, p. 83).

54 The caselaw is sparse on this point, but what there is supports the claim. See, e.g. United States v. Moore, 10 M.J. 354, 358 n.4 (C.M.A. 1983) (holding that the defendant in a rape case was not entitled to a "mistake of fact" instruction, even assuming arguendo that there was evidence the victim had "irrevocably consented to" sex, because a victim's irrevocable prospective consent would not override her contemporaneous nonconsent).

55 Westen's otherwise excellent account of prospective and retrospective consent does not discuss security agreements as a form of valid irrevocable prospective consent. Westen (2004, pp. 247-268) (chapter titled "Non-contemporaneous Prescriptive Consent"). I am indebted to an anonymous reviewer for offering a criticism that led me to recognize how security agreements involve irrevocable prospective consent.

56 Reiley (1999-2010 § 2:1).

57 See, e.g., First Nat. Bank \& Trust Co. v. State, 233 S.E.2d 861 (Ga. App. 1977) (holding that employees of bank were not guilty of theft of automobile or personal property seized pursuant to valid security agreement).

58 Sperry v. ITT Commercial Finance Corp., 799 S.W.2d 871, 878-879 (Mo. App. W.D. 1990).
} 
Thus the security agreement is the one instance in which the criminal law recognizes that $S$ 's irrevocable prospective consent overrides her equally voluntary, contemporaneous non-consent.

\section{The Marital Rape Exemption}

The most notorious historical example of irrevocable prospective consent in the criminal law is the marital rape exemption: the common law rule that a husband could not rape his wife. In the past, this exemption was justified by Sir Matthew Hale's reasoning that "by their mutual matrimonial consent and contract the wife hath given up herself in this kind unto her husband, which she cannot retract." ${ }^{59}$ A husband could not rape his wife, the law held, because the wife gave irrevocable prospective consent to sex by agreeing to marriage.

The marital rape exemption has undergone intense and sustained criticism. ${ }^{60}$ While many American jurisdictions maintain some distinctions between rape within and outside of marriage, ${ }^{61}$ the rule of "irrevocable prospective consent to sex" is no longer recognized in any American jurisdiction. ${ }^{62}$ In 1991 the British House of Lords squarely rejected Hale's notion of "irrevocable prospective consent" to marital sex. ${ }^{63}$

Particularly notable is the shift in underlying rationales behind the marital rape exemption and its permutations. The traditional argument relied on irrevocable prospective consent; marital status rules "conclusively inferred consent from a person's initial agreement to marry." ${ }^{64}$ More recently, the "irrevocable prospective consent" justification has been dropped entirely, even in those jurisdictions where some form of the marital rape exemption persists. Every American case since at least 1981 has rejected Hale's irrevocable consent theory as a justification for any form of the marital rape exemption. ${ }^{65}$ Contemporary defenders of some form of the marital rape exemption rely on entirely different arguments: "protecting the privacy of the marital relationship," "facilitat[ing] marital reconciliation," and "prevent[ing] wives from pursuing false charges of marital

\footnotetext{
59 Hale (1847, p. 628).

60 See, e.g., Anderson (2003, pp. 1466 n.3, 1470-1471) (citing other critics); Model Penal Code § 213.1, p. 343, Comment (1980); Brownmiller (1975, p. 381).

61 Some states "require a couple to be separated at the time of the injury," some require proof of "physical force and/or serious physical injury," and some "provide for vastly reduced penalties" for rape within marriage. Hasday (2000, p. 1484 \& nn. 407-411).

62 The most recent American case to affirm an acquittal or reverse a conviction for rape or sexual assault based on the irrevocable prospective consent rationale is from 1944. State v. Ward, 28 S.E.2d 785, 787 (S.C. 1944).

63 Regina v. R., [1991] UKHL 12 (House of Lords) ("Hale's proposition involves that by marriage a wife gives her irrevocable consent to sexual intercourse with her husband... In modern times any reasonable person must regard that conception as quite unacceptable."). In 1993 the United Nations Declaration on the Elimination of Violence against Women likewise recognized "marital rape" as a form of criminal "violence against women." General Assembly Resolution 48/104 (1993).

64 Hasday (2000, p. 1392). The marital rape exemption did not serve as a defense to sexual assault in cases where the wife's entry into the marriage contract had been forced or otherwise deemed non-consensual. Hasday (2000, p. 1399).

65 See, e.g., In re Estate of Peters, 765 A.2d 468, 474 (Vt. 2000) ("We reject entirely the notion that marriage creates any kind of implied 'blanket consent to sexual contact." "); People v. M.D., 595 N.E.2d 702, 710-711 (Ill. App. 2 Dist. 1992) ("Lord Hale's implied consent theory...is...objectionable..., depriving women of their dignity by refusing to recognize them as whole human beings who are entitled to decide whether or when they will engage in sexual relations...); Shunn v. State, 742 P.2d 775, 778 (Wyo. 1987) ("Today, Hale's theory is both unrealistic and unreasonable.").
} 
rape." ${ }^{66}$ Much has been said about these purported justifications for some form of a marital rape exemption. ${ }^{67}$ But one thing is clear: the criminal law has wholly abandoned the notion that a wife irrevocably consents to sex by agreeing to marriage, or that any such irrevocable consent provides a defense to a rape charge.

In summary, the criminal law tends "to privilege contemporaneous expressions of consent or nonconsent over prior conflicting preferences." 68 The criminal law does recognize irrevocable prospective consent, however, when (1) $S$ later suffers under significantly diminished capacity, or (2) $S$ gives irrevocable consent to the seizure of her property in a security agreement.

\section{The Theory of Prospective Consent: Mill, Feinberg, Raz}

What light does this doctrinal description of prospective consent shed on the justification for consent? Westen argues that Mill's "self-interest" theory is consistent with this state of the doctrine. In contrast, "if doctrines of prospective prescriptive consent were based on [Feinberg's] notions of $S$ 's autonomy (as opposed to $S$ 's interests), jurisdictions would recognize prospective prescriptive consent far more widely than they presently do, rather than treating it as an exception to a normative presumption in favor of contemporaneous consent." ${ }^{69}$ These points are addressed in turn.

\section{Mill's Self-Interest Theory is Consistent with Prospective Consent Doctrine}

Westen first claims that the criminal law's approach to prospective consent can be explained by Mill's "self-interest" theory. Under Mill's theory, $S$ 's consent to $x$ with $A$ is a defense to a criminal charge because $S$ is the best judge of whether $x$ furthers her interests. With this understanding of consent, it makes sense that jurisdictions recognize $S$ 's irrevocable prospective consent "when $S$ "s relative competence to perceive and assess her selfinterests is expected to substantially diminish by the time the future conduct occurs."70 Jurisdictions permit $S$ 's prospective consent to override her contemporaneous non-consent in those cases where we can reliably determine that her ability to perceive and assess her self-interest will be substantially diminished.

The criminal law's recognition of the irrevocable prospective consent embodied in a security agreement is also consistent with this theory. If $S$ is the best judge of her own interests, it is not surprising that the law might also decide that $S$ is the best judge of whether constraining her future choice-by irrevocably consenting to lender $A$ 's seizure of her property if she defaults-is also in her interests. So long as $S$ herself decides to make her consent to $A$ 's seizure of her property expressly irrevocable, we are in no position to second-guess her.

This leads to the question of whether the criminal law, if motivated by Mill's selfinterest theory, should recognize irrevocable prospective consent even more broadly than it does, by generally allowing $S$ to do what she is permitted to do only in the context of a

\footnotetext{
$\overline{66}$ Hasday (2000, pp. 1487-1488).

${ }^{67}$ Hasday criticizes these rationales at pp. 1486-1504. See also People v. De Stefano, 121 Misc.2d 113, 120

(N.Y. Co. Ct. 1983) (citing articles).

${ }^{68}$ Husak (2010, p. 116).

69 Westen (2004, p. 263).

70 Westen (2004, p. 263).
} 
security agreement: make her decision about her self-interest ahead of time, and also make that choice irrevocable.

Husak argues that "an abundance of data confirms that persons are notoriously poor in predicting what they will want at a later time under different circumstances." ${ }^{71}$ Husak thus questions why the law would "privilege their earlier judgment when they express a preference for a future contingency they can barely imagine."72 This may explain why, on a Millian "self-interest" theory, the criminal law is right to rarely recognize prospective consent. Husak in essence appeals to the ability of the individual to best assess her own interests (Mill's concern), and argues that what we know of human psychology tells us to be skeptical of individuals' skill at assessing their future interests. Accepting Husak's argument, and adopting the Millian view of consent, we would conclude that the criminal law properly refuses to recognize irrevocable prospective consent, except in cases of diminished capacity and security agreements.

\section{Feinberg's Sovereign Autonomy Theory is Not Consistent with Prospective Consent Doctrine}

Westen claims that "if doctrines of prospective prescriptive consent were based on [Feinberg's] notions of $S$ 's autonomy (as opposed to $S$ 's interests), jurisdictions would recognize prospective prescriptive consent far more widely than they presently do, rather than treating it as an exception to a normative presumption in favor of contemporaneous consent." ${ }^{73}$ I agree; current criminal law doctrine cannot be adequately explained by Feinberg's "sovereign autonomy" theory.

Recall that for Feinberg, $S$ 's autonomy stems from her intrinsic sovereignty over her self. When $S$ chooses to give irrevocable prospective consent to $x, S$ is purporting to trade away or alienate her future autonomous choice. Husak notes that Feinberg "seemingly believes not only that prior fully voluntary consent is relevant, but also that it is decisive." ${ }^{74}$ Feinberg does indeed privilege (voluntary) irrevocable prospective consent, precisely because his commitment to self-sovereignty leads him there. If $S$ 's right to autonomy is based on the simple fact of her ownership of her life, she should be permitted to alienate or barter that right away, just as with other rights she owns.

It is surely true that one can be "autonomous," in at least some senses of that word, and yet not retain the power to alienate one's future autonomy. (Raz's conception of autonomy, discussed below, is one example.) But the right to alienate one's autonomy is implicit in Feinberg's particular conception of autonomy, namely a right self-sovereignty. If the law took Feinberg's view that $S$ possesses a right to autonomy because it is "after all his life; it belongs to him and to no one else," then $S$ alone "must be the one to decide-for better or worse-what is to be done with it." 75 So long as $S$ 's irrevocable alienation of his future autonomy does not injure someone else, the criminal law has no basis to deny $S$ the right to alienate what is his by birthright. A person with an intrinsic right of autonomy based on his self-sovereignty will, in Feinberg's words, "surely... reserve the right to 'trade off' his de

\footnotetext{
71 Husak (2010, p. 120).

72 Husak (2010, p. 120).

73 Westen (2004, p. 263)

74 Husak (2010, p. 119).

75 Feinberg (1989, p. 59).
} 
facto freedoms for goods of other kinds, as measured on his own scale of values and determined by his own judgments."76

Husak objects that Feinberg "pushes the idea of personal sovereignty too far," again citing the literature showing that individuals are bad at predicting their future interests. ${ }^{77}$ This highlights the implications of Feinberg's conception of autonomy: Feinberg values autonomy (and, correspondingly, irrevocable consent) not because he disagrees with the psychological literature and believes individuals will accurately predict their future interests. Instead, $S$ 's self-sovereignty is part of her birthright, to use for good or ill. If this pushes the idea of autonomy "too far," that simply reflects a rejection of the notion of autonomy as an intrinsic right of sovereign self-ownership.

As noted above, the criminal law does not generally recognize $S$ 's power to voluntarily alienate or barter away her future freedom, including her future freedom of choice. Thus Feinberg's conception of "sovereign autonomy" is inconsistent with the criminal law's presumption against irrevocable prospective consent.

\section{Raz's "Autonomy is Good" Theory is Consistent with Prospective Consent Doctrine}

Unlike Feinberg, Raz does not view autonomy as $S$ 's sovereign birthright. Instead, Raz argues that $S$ 's right to autonomy stems from the government's view that being autonomous is an essential element of the good life for $S$.

A criminal law based on Raz's "autonomy is good" theory would be wary that $S$ 's irrevocable consent to $x$ should be honored over her contemporaneous non-consent, because irrevocable prospective consent amounts to $S$ attempting to reject or trade away the one thing the law seeks to secure for her as an element of the good life-her autonomy. By purporting to bind her future decision-making powers through irrevocable prospective consent, $S$ is choosing something else (for example, spiritual selfabnegation, freedom for her children, or money for a good cause) in exchange for alienating her future right to self-determination. On Feinberg's conception of autonomy as self-sovereignty, $S$ should have the right to trade her autonomy for something else: the "perfectly autonomous person would have... the 'power of voluntarily disposing of his own lot in life,' even if that involved forfeiting his de facto freedom in the future."78

But if we value $S$ 's autonomy because her autonomy is a constituent element of a good and worthy life, it stands to reason that the law might not permit $S$ to abandon or abdicate that good. $S$ 's self-determination is a good the government secures for her in its function of "promot[ing] morality," specifically promoting "the advancement of the well-being of individuals." 79 The government seeks to enable $S$ to live autonomously so she can "adopt and pursue goals because [she] believes in their independent value." This is true even if $S$ does not want her autonomy. The state has an independent interest in

\footnotetext{
76 Feinberg (1989, p. 65).

77 Husak (2010, p. 120).

78 Feinberg (1989, p. 69) (quoting Mill (1859, Ch. V para. 10)).

79 Raz (1988, pp. 415, 267).
} 
promoting $S$ 's well-being (in the form of living an autonomous life), whether $S$ desires that life or not.

Mill explains that "by selling himself for a slave, [an individual] abdicates his liberty; he foregoes any future use of it beyond that single act. He therefore defeats, in his own case, the very purpose which is the justification of allowing him to dispose of himself." ${ }^{80}$ If the state of being autonomous itself is the good society seeks to secure, then Mill's observation is true: by abdicating her future liberty, $S$ defeats, in her own case, "the very purpose" - enabling $S$ to live an autonomous life- "which is the justification of allowing [her] to dispose of [her]self." 81

By refusing to recognize $S$ 's irrevocable prospective consent, the criminal law appears to be recognizing that "it is the function of governments to promote... morality," at least in the form of "the advancement of the well-being of individuals" through living autonomously. ${ }^{82}$ Society pursues this moral good for $S$ based on society's judgment that being autonomous is an essential element of $S$ leading a good, worthy life.

The "autonomy is good" theory also accounts for the criminal law's recognition of the irrevocable prospective consent embodied in a valid security agreement. By recognizing irrevocable consent in the narrow context of security agreements, the criminal law facilitates $S$ 's pursuit of a good, worthy life. Security agreements dramatically expand the availability of credit to borrowers, thereby facilitating economic growth, increased purchasing power, and higher standards of living. ${ }^{83}$ Generally speaking the law refuses to recognize $S$ 's attempt to alienate her future autonomy, because being autonomous is an element of the good life. But when $S$ seeks to irrevocably consent to the future seizure of her property (in the event she defaults), the law recognizes that $S$ 's well-being is enhanced, not diminished, by facilitating this sort of transaction. Because autonomy is an element of $S$ 's well-being, $S$ 's choice to restrict her future autonomy in a limited way that significantly enhances her overall well-being is a choice the law is willing to endorse.

Thus Raz's theory-that consent is honored in the criminal law because "being autonomous is good" for individuals - adequately explains the criminal law's approach to prospective consent.

\section{Retrospective Consent and the Criminal Law}

The very notion of retrospective consent is more troublesome to most commentators than that of prospective consent. Feinberg writes, "[t]here is very little that can be done, despite the ingenious efforts of some philosophers, to extract coherence from the strange notion of 'subsequent consent." 84 Husak similarly notes, "[i]t is unlikely that consent can be

\footnotetext{
${ }^{80}$ Mill (1859, p. 158).

81 Mill's comment here does not seem consistent with his own explanation of the justification for honoring $S$ 's consent. If we value $S$ 's consent because $S$ is the best judge of her own interests, it is not clear why $S$ 's irrevocable consent to voluntary slavery "therefore defeats, in his own case, the very purpose which is the justification of allowing him to dispose of himself." Mill (1859, p. 158). Don Regan notes that "[t]here is a certain looseness here"-it is not difficult to imagine cases where a person "might have what seems to her a very strong reason for wanting to sell herself into slavery," such as securing a life-saving operation for her child. Regan (1983, p. 117).

$82 \operatorname{Raz}(1988$, pp. 415, 267).

83 Reiley (1999-2010, § 2:1).

84 Feinberg (1989, p. 182).
} 
retrospective." 85 Donald VanDeVeer states, "[i]f there is something to which "subsequent consent' refers (there may not be, as we have noted) it will be a later 'approval' or 'positive attitude' toward a prior event. However, this hardly counts as a giving of permission or a relinquishing of a right." ${ }^{86}$ Perhaps reflecting the general disparagement of the idea of retrospective consent, Alan Wertheimer's book-length treatment of consent in the context of sexual relations says only, "I prefer to avoid appeals to retrospective consent." 87

Westen is less dismissive of the concept, noting that " $[t]$ he notion of subsequent consent has an ancient pedigree. The Statute of Westminster of 1285 made it a crime to 'ravish a woman... where she neither assented before nor after." ${ }^{88}$ Eric Chwang has likewise published "A Defense of Subsequent Consent." ${ }^{89}$ I share their view that the concept of retrospective consent is more plausible, and makes more sense, than many commentators have allowed.

Specifically, the coherence of "retrospective consent" depends on what purpose we believe consent is serving. If the purpose of consent is to honor $S$ 's autonomy, then commentators are correct to say that retrospective consent is not a coherent concept. On the other hand, if we honor consent because $S$ is the best judge of her own interests, then retrospective consent is a coherent concept, and may be entitled to some normative force.

The Doctrine of Retrospective Consent in the Criminal Law

As a descriptive matter, the criminal law's approach to retrospective consent is easy to summarize: the criminal law does not recognize retrospective consent as a defense, or indeed give it any normative significance whatsoever (as it might, for example, by holding that retrospective consent turns a completed offense into an attempted offense). One oftquoted decision states that "[i]t has never been regarded as a legal excuse for the consummated offence [of rape] that the woman consented after the fact." ${ }^{90}$ This is the consensus view. ${ }^{91}$

\section{Retrospective Consent and the Awakened Lover}

Westen proposes an example of non-criminal sexual intercourse where consent is only given after the fact, and which might sanction otherwise criminal conduct:

$S$ and $A$ are lovers who, having made love earlier in the evening, both fall asleep. $A$ awakens at 3:00 a.m. and finding $S$ still asleep, initiates the act of sexual intercourse with her while she is sleeping. During the course of the act, $S$ awakens, embraces $A$, saying, "This is nice-we should do it this way again." Ruling: The

\footnotetext{
85 Husak (2010, p. 114).

86 VanDeVeer (1986, p. 69).

87 Wertheimer (2003, p. 156).

88 Westen (2004, p. 254 (emphasis in Westen)).

89 Chwang (2009).

90 State v. Hartigan, 32 Vt. 607, 1860 WL 4943 (1860). See also Battle v. State, 414 A.2d 1266, 1269 (Md. 1980) (citing authorities).

91 See, e.g., 65 Am. Jur. 2d Rape $\$ 7$ ("The ultimate consent of the woman does not have a retroactive effect...."); LaFave and Scott $§ 57$ (1972).
} 
courts rule that, based on $S$ 's subsequent ratification of what $A$ did while she was asleep, $A$ has a defense of consent to a criminal charge of rape. ${ }^{92}$

In support of this "Ruling," Westen cites three cases as examples: Regina v. Barrow, ${ }^{93}$ Pollard v. State, ${ }^{94}$ and Regina v. Clarke. ${ }^{95}$ These cases, however, do not withstand scrutiny as examples of courts recognizing retrospective consent. All three involve a sleeping woman awakened by sexual advances. It is not clear, as a factual matter, that Barrow and Clarke involve retrospective-as opposed to contemporaneous-consent. ${ }^{96}$ More importantly, the court in each case analyzed the issue through the lens of consent obtained by fraudulent identity, not retrospective consent. ${ }^{97}$ In both cases the courts quite clearly rest their holdings on the old common law rule that consent, even when obtained through impersonating the victim's husband, served as a valid defense to the charge of rape. The Pollard case more squarely presented the question of retrospective consent, but the court interpreted the controlling statute in a way that permitted it to bypass the significance, if any, of retrospective consent. ${ }^{98}$

Thus, as a descriptive matter, there is no meaningful support in British or American law for the notion that consent upon awakening during sexual intercourse constitutes legally valid retrospective consent or legitimizes what otherwise would be criminal conduct.

\section{Retrospective Consent and "Private" Offenses Against Property}

Retrospective consent has been recognized-rarely-as a defense in the context of a few property crimes. It is notable that there are any criminal cases holding that $S$ 's retrospective

\footnotetext{
92 Westen (2004, p. 254). Alan Wertheimer discusses a similar example and likewise concludes that $A$ 's conduct is not illegal. Wertheimer does not, however, share Westen's view that retrospective consent explains the permissibility of $A$ 's conduct. Instead, Wertheimer argues this example "shows that it is a mistake to conceptualize the wrong of nonconsensual intercourse purely as a violation of someone's bodily boundaries or one's sexual autonomy." Wertheimer (2003, p. 156). If the conduct in question is legally permissible, but for reasons other than retrospective consent, this is consistent with the present doctrinal claim that the criminal law never gives normative force to retrospective consent.

9311 Cox Crim. Cas. 191 (1868).

942 Iowa 567 (1856).

956 Cox Crim. Cas. 412 (1854).

${ }^{96}$ In both opinions, the opening statement of facts does suggest that the sleeping victim's consent occurred after the defendant had initiated sexual intercourse, although neither opinion is completely clear. Once the legal analysis begins, however, each case elides the question of retrospective consent by focusing instead on the question of fraudulent identity, effectively treating the consent as contemporaneous. The courts seem to misread the record so as to avoid the thorny question of retrospective consent. See Wald (1995) (noting the common tendency of courts to deliberately or inadvertently mis-read the record so as to avoid difficult issues).

97 Barrow, 11 Cox Crim. Cas. at 192 ("We are of the opinion that this case comes within that class of cases in which it has been decided that where, under such circumstances, consent has been obtained by fraud, the offense does not amount to rape."); Clarke, 6 Cox Crim. Cas. at 413. The reporter's headnotes preceding both Barrow and Clarke also show that the cases were understood as raising the question of fraudulent identity, not retrospective consent. Barrow is categorized as involving "Rape-Consent-Fraud," and Clarke is categorized as a case of "Rape-Consent-Carnal connexion under circumstances which induce the woman to believe the man is her husband," a headnote abbreviated in the index as "Rape-Consent induced by fraud."

98 The court held the statute in question, Code of Iowa $§ 2582$ (1850), did "not call for affirmative evidence of consent, on the part of the defendant, but evidence of dissent and repulsion, on the part of the state." Pollard, 2 Iowa 567, 1856 WL 131, *3 (1856). Thus a defendant who initiated sex with a sleeping victimwho did not actively dissent but simply failed to affirmatively consent-had not violated the statute so interpreted.
} 
consent served as a defense to $A$ 's earlier (non-consensual) conduct. But rather than establishing some important exception, these cases actually serve to reinforce the point that the criminal law, properly understood, does not recognize retrospective consent.

In Holsey v. State, the defendant was convicted of a misdemeanor under the Georgia Penal Code: "'willfully rid[ing] or driv[ing] any horse or mule belonging to another, without his consent." 99 After the defendant had ridden a mule without the owner's consent, the owner "gave the defendant the choice of taking a whipping or paying for the horse." The defendant chose the latter, paid for the horse, but nonetheless was prosecuted. The court reversed the conviction, relying on the "old and well-recognized" civil rule that a person whose property has been converted by another may elect to reclaim the property or sue for its value. Prosecution was barred "where before the institution of the prosecution the owner of the animal, either for or without a consideration, has given acquiescence, or, so to speak, ex post facto consent to the previously unauthorized use of his property." 100

The court quickly noted that retrospective consent ordinarily has no effect in the criminal law: "[t]his ruling is to be taken, however, with the understanding that the principle is applicable only in that class of cases where the offense involves no crime against society or good morals, but relates solely to the redressing of private property wrongs." 101

Thus, the retrospective consent defense applied precisely because the court interpreted the criminal statute as addressing solely a private wrong. A widely-recognized difference between criminal law and civil law-perhaps the key difference-is that criminal law serves to punish offenses against the community at large, whereas civil law provides redress for offenses against an individual. ${ }^{102}$ The Georgia offense of non-consensual muleriding was really a civil offense that had migrated into the penal code — so the Georgia court decided to retain the essentially civil nature of the offense by recognizing a civil defense resembling retrospective consent.

Thus, as a descriptive matter, the criminal law does not accord any normative value to retrospective consent.

The Theory of Retrospective Consent: Mill, Feinberg, Raz

The criminal law's total rejection of retrospective consent can be explained by either Feinberg's "sovereign autonomy" theory or Raz's "autonomy is good" theory, but cannot be explained by Mill's "self-interest" theory. These points are addressed in turn.

\section{Feinberg's Sovereign Autonomy Theory is Consistent with the Law's Rejection of Retrospective Consent}

Westen explains that "autonomy succeeds better than self-interest in explaining the feature that is so distinctive of retrospective prescriptive consent-namely, its striking rarity as an

\footnotetext{
99 Holsey v. State, 61 S.E. 836, 836 (Ga. App. 1908) (quoting Georgia Penal Code $§ 225$ (1895)).

100 Ibid.

101 Ibid.

102 Fletcher (1998, p. 39); Blackstone (1769, p. 5) ("THE distinction of PUBLIC WRONGS. from private, of crimes and misdemeanors from civil injuries, seems principally to consist in this: that private, or civil injuries, are an infringement or privation of the civil rights which belong to individuals, considered merely as individuals; wrongs, or crime and misdemeanors, are breach and violation of the public rights and duties, due to the whole community, considered as community, in its social aggregate capacity.”).
} 
official defense." 103 If our concern is $S$ 's right to autonomy-her right to determine the course of events in her life-then $S$ 's after-the-fact consent has no bearing on our concern: "the one goal that retrospective consent is incapable of achieving... is the goal of enhancing $S$ 's autonomy to engage in $x$, because by the time $S$ retrospectively consents to $x$, she can no longer influence whether $x$ has occurred in the past." 104

Any understanding of consent that depends on vindicating $S$ 's autonomous choice suffices to explain the hostility of the law-and of many commentators-to the very coherence of the notion of retrospective consent. In terms of $S$ exercising her autonomychoosing the course her life will take- $S$ 's later evaluation of her earlier choice is not relevant. Whatever $S$ 's later desires or opinions might be, those feelings cannot retrospectively affect the unfolding course of her life events. Thus Feinberg's "sovereign autonomy theory" - a theory focused on vindicating $S$ 's autonomous choice-is fully consistent with the criminal law's rejection of retrospective consent.

\section{Mill's Self-Interest Theory is Not Consistent with the Law's Rejection of Retrospective Consent}

Unlike Feinberg's "sovereign autonomy theory," Mill's theory of self-interest fails to explain the criminal law's wholesale rejection of retrospective consent. Westen explains, "if $S$ 's self-interest were the goal that jurisdictions invoked retrospective consent to serve, jurisdictions would recognize the legitimacy of retrospective consent far more often than they presently do, for $S$ knows the most about herself after $x$ occurs when she is able to place it in the context of her life as a whole." 105

As Westen correctly observes, one's ability to judge a given event is usually at its highest and most reliable point after that event has occurred: my opinion of a movie is of little value before I see it (based on my preconceptions), of some greater value during the movie (based on my contemporaneous evaluations), and of the greatest value some time after the movie (having reflected on the entire experience). Westen correctly goes so far as to claim that "if $S$ 's self-interest were the controlling consideration, jurisdictions would always measure the harm of nonconsensual offenses by what $S$ perceives her interests to be afterwards." 106

Accordingly, if consent were valued in the criminal law because we believe $S$ is the best judge of her own interests, the concept of retrospective consent would not be incoherent or empty. Donald VanDeVeer asks "how subsequent consent is supposed to 'reach back in time'... and legitimize the past act." 107 The "self-interest" theory shows how this could be true. Retrospective consent can never "reach back in time" and change what happened. But it could (on this theory) reach back and change the moral import of past events. If the law is concerned with whether $x$ served $S$ 's interests - and in particular, deferring to $S$ 's judgment of whether $x$ advanced her interests - then $S$ 's retrospective consent should fully satisfy the law's concern (assuming sufficient conditions of knowledge, competence, and freedom). So understood, "retrospective consent" does not represent a choice about what events will occur - that cannot be altered by retrospective consent—but rather a choice

\footnotetext{
103 Westen (2004, p. 263).

104 Westen (2004, p. 263).

105 Westen (2004, p. 263).

106 Westen (2004, p. 263).

107 VanDeVeer (1986, p. 69).
} 
about whether given events served $S$ 's interests, in her own estimation. The question "Did $S$ consent?" could be reformulated as, "Did $S$ indicate that $x$ serves (or served) her interests?"

Note that this formulation is consistent with the definition of "consent" given at the outset: a communicative act by $S$ to conduct $x$ by $A$ which alters the moral rights and duties of $S$ and $A$ relative to each other. ${ }^{108}$ Consent here is $S$ 's act of expressing her preference about past conduct, in a manner that changes her rights (here, whether those rights were violated).

Of course, one might well argue that what promotes $S$ 's interests is being in control of what happens to herself, and such control can only be exercised by prospective or contemporaneous consent, not by retrospective consent. But this argument entails rejecting Mill's explanation of why we value consent, namely because $S$ is the best judge of what serves her interests. Instead, this argument claims that what serves $S$ 's interest is her ability to control what happens to her-to be autonomous. This is, in other words, a version of Raz's conception of autonomy.

The notion of retrospective consent strikes many as strange or incoherent. This simply reflects the fact that we do not understand consent as solely vindicating $S$ 's interests according to her own opinion. If we held that conception, retrospective consent would make sense. Because we do not, the concept rightly appears strange and incoherent.

\section{Raz's "Autonomy is Good" Theory is Consistent with the Law's Rejection of Retrospective Consent}

Raz's theory, like Feinberg's, is able to explain the criminal law's total rejection of retrospective consent. As noted above, any understanding of consent that depends on vindicating $S$ 's autonomous choice will reject the validity of retrospective consent. Regardless of whether society values autonomy because it is an inherent right (Feinberg), or because being autonomous is good for the individual (Raz), it remains the case that "the one goal that retrospective consent is incapable of achieving...is the goal of enhancing $S$ 's autonomy to engage in $x$, because by the time $S$ retrospectively consents to $x$, she can no longer influence whether $x$ has occurred in the past." ${ }^{109}$ Insofar as autonomy is the underlying value, it is true that " $[\mathrm{t}]$ here is very little that can be done...to extract coherence from the strange notion of "subsequent consent.", 110

\section{Conclusion}

The unusual doctrines of prospective and retrospective consent cast a unique light on the underlying justification for consent in the criminal law. The three classically liberal conceptions identified herein-Mill's "self-interest" theory, Feinberg's "sovereign autonomy" theory, and Raz's "autonomy is good" theory-all have broadly similar implications for the more common debates over the degrees of freedom, knowledge, and competence required for legally valid consent. But the issue of non-contemporaneous consent highlights the real differences of these competing conceptions. The criminal law's total rejection of the strange notion of retrospective consent, along with its very limited

\footnotetext{
${ }^{108}$ Hyams (2011, p. 111); Kleinig (2010, p. 5).

109 Westen (2004, p. 263).

${ }^{110}$ Feinberg (1989, p. 182).
} 
recognition of irrevocable prospective consent, embodies Raz's theory that it is the proper role of the state to promote morality, in particular the moral good of individual well-being in the form of an autonomous life.

Theorists who argue in favor of Mill's self-interest theory must grapple with the implications for retrospective consent: that the criminal law should recognize that retrospective consent has at least some normative force in evaluating whether $A$ 's conduct $x$ was an offense against $S$. Conversely, those who share the broadly-held intuition that retrospective consent should have no moral force must recognize that this conclusion entails a rejection of Mill's "self-interest" conception of consent.

Theorists who argue in favor of Feinberg's "sovereign autonomy" theory must grapple with the implications for prospective consent (as Feinberg himself does): namely, that the criminal law should presumptively recognize $S$ 's irrevocable prospective consent, in contrast to the law's current approach of presumptively rejecting the validity of irrevocable prospective consent. Conversely, those who hold the intuition that the law should generally privilege $S$ 's contemporaneous expression of non-consent over her earlier irrevocable consent should recognize that this approach entails rejecting Feinberg's "sovereign autonomy" theory.

I have not articulated an endorsement or defense of Raz's moral perfectionist theory of the liberal state, or his conception of autonomy within that theory. Instead, I have explained how Raz's conception of "autonomy is good" suffices to explain why the criminal law treats prospective consent and retrospective consent as it does. However, to the extent the criminal law's existing approach to non-contemporaneous consent meshes with our moral intuitions about how the state should treat $S$ 's consent, we must recognize that Raz's theory of autonomy best explains those intuitions. The criminal law reflects Raz's view that it is the duty of the state to promote morality, in particular the moral good of individual well-being in the form of an autonomous life.

Acknowledgments Special thanks to Peter Westen for his very helpful feedback on drafts of this article. Thanks to two anonymous Criminal Law and Philosophy referees, whose incisive comments helped greatly improve the paper. Thanks also to Caroline Mala Corbin, Dena Davis, Patti Falk, Peter Garlock, Brian Ray, and John E. Taylor for their careful reading and helpful comments. Thanks to Maria Witmer-Rich for her unending support and encouragement.

\section{References}

Anderson, M. J. (2003). Marital immunity, intimate relationships, and improper inferences: A new law on sexual offenses by intimates. Hastings Law Journal, 54, 1465.

Blackstone, W. (1769). Commentaries on the Laws of England, 4.

Brownmiller, S. (1975). Against our will: Men, women, and rape. New York: Random House.

Chwang, E. (2009). A defense of subsequent consent. Journal of Social Philosophy, 40, 1.

Feinberg, J. (1989). Harm to self. Oxford: Oxford University Press.

Fletcher, G. P. (1998). Basic concepts of criminal law. Oxford: Oxford University Press.

Hale, M. (1847). Historia Placitorum Coronae (1st Am. ed.).

Hasday, J. E. (2000). Contest and consent: A legal history of marital rape. California Law Review, 88, 1373. Homer. The Odyssey, Book XII.

Hurd, H. (1996). The moral magic of consent. Legal Theory, 2, 121.

Husak, D. (2010). Paternalism and consent. In A. Wertheimer \& F. G. Miller (Eds.), The ethics of consent. Oxford: Oxford University Press.

Hyams, K. (2011). When consent doesn't work: A rights-based case for the limits on consent's capacity to legitimize. Journal of Moral Philosophy, 8, 110.

Kleinig, J. (2010). The nature of consent. In F. G. Miller \& A. Wertheimer (Eds.), The ethics of consent: Theory and practice. Oxford: Oxford University Press. 
LaFave, W., \& Scott, A. (1972). Handbook on criminal law. St. Paul, MI: West.

Mill, J. S. (1859). On liberty.

Miller, F. G., \& Wertheimer, A. (2010). Preface to a theory of consent transactions: Beyond valid consent. In F. G. Miller \& A. Wertheimer (Eds.), The ethics of consent: Theory and practice. Oxford: Oxford University Press.

Raz, J. (1988). The morality of freedom. Oxford: Oxford University Press.

Reiley, E. H. (1999-2010). Security interests in personal property. Clark Boardman Callaghan.

Regan, D. (1983). Paternalism, freedom, identity, and commitment. In R. Sartorius (Ed.), Paternalism. Minneapolis: University of Minneapolis Press.

Simmons, A. J. (2010). Political obligations and consent. In F. G. Miller \& A. Wertheimer (Eds.), The ethics of consent: Theory and practice. Oxford: Oxford University Press.

VanDeVeer, D. (1986). Paternalistic intervention: The moral bounds of benevolence. Princeton, NJ: Princeton University Press.

Wald, P. M. (1995). The rhetoric of results and the results of rhetoric: Judicial writings. University of Chicago Law Review, 62, 1371.

Wertheimer, A. (2003). Consent to sexual relations. Cambridge: Cambridge University Press.

Westen, P. (2004). The logic of consent: The diversity and deceptiveness of consent as a defense to criminal conduct. Aldershot: Ashgate.

\section{Other}

65 Am. Jur. 2d Rape $\S 7$.

Model Penal Code, $§ 213.1$, at 343, Comment (1980).

Declaration on the Elimination of Violence Against Women, General Assembly Resolution 48/104, U.N. G.A.O.R., 48th Session, U.N. Doc. A/RES/48/104 (1993) 217.

\section{Cases}

Battle v. State, 414 A.2d 1266, 1269 (Md. 1980).

First Nat. Bank \& Trust Co. v. State, 233 S.E.2d 861 (Ga. App. 1977).

Holsey v. State, 61 S.E. 836, 836 (Ga. App. 1908).

In re Estate of Peters, 765 A.2d 468, 474 (Vt. 2000).

People v. De Stefano, 467 N.Y.S.2d 506, 512 (N.Y. Co. Ct. 1983).

People v. M.D., 595 N.E.2d 702, 710-11 (Ill. App. 2 Dist. 1992).

Pollard v. State, 2 Iowa 567, 1856 WL 131, *3 (1856).

Regina v. Barrow, 11 Cox Crim. Cas. 191, 192 (1868).

Regina v. Clarke, 6 Cox Crim. Cas. 412, 413 (1854).

Regina v. R., [1991] UKHL 12 (House of Lords).

Shunn v. State, 742 P.2d 775, 778 (Wyo. 1987).

Sperry v. ITT Commercial Finance Corp., 799 S.W.2d 871 (Mo. App. W.D. 1990).

State v. Hartigan, 32 Vt. 607, 1860 WL 4943 (1860).

State v. Ward, 28 S.E.2d 785, 787 (S.C. 1944).

Tyson v. Trigg, 50 F.3d 436, 448 (7th Cir. 1995).

United States v. Moore, 10 M.J. 354, 355 (C.M.A. 1983). 